\title{
Acetic acid as an intervention strategy to decontaminate beef carcasses in mexican commercial slaughterhouse
}

Laura Reyes CARRANZA¹, Maria Salud Rubio LOZANO ${ }^{1 \star}$, Ruben Danilo Méndez MEDINA, Maria del Carmen Wacher RODARTE², Jose Fernando Núñez ESPINOSA 3 , Bertha Lucila Velázquez CAMACHO 3 , Renata Ernlund Freitas MACEDO ${ }^{4}$

\begin{abstract}
Beef can be contaminated during the slaughter process, thus other methods, besides the traditional water washing, must be adopted to preserve meat safety. The objective of this study was to evaluate the effect of $2 \%$ acetic acid interventions on the reduction of indicator bacteria on beef carcasses at a commercial slaughterhouse in Mexico. Reduction was measured by the count of mesophilic aerobic bacteria (TPC), total coliform (TC), and fecal coliform (FC) $\left(\log \mathrm{CFU} / \mathrm{cm}^{2}\right)$. Among the different interventions tested, treatments combining acetic acid solution sprayed following carcass water washing had greater microbial reduction level. Acetic acid solution sprayed at low pressure and longer time (10-30 psi/ $60 \mathrm{~s})$ reached higher TPC, TC, and FC reductions than that obtained under high pressure/ shorter time $(1,700 \mathrm{psi} / 15 \mathrm{~s} ; \mathrm{P}<0.05)$. Exposure time significantly affected microbial reduction on carcasses. Acetic acid solution sprayed after carcass washing can be successfully used to control sources of indicator bacteria on beef carcasses under commercial conditions.
\end{abstract}

Keywords: bovine carcass; acid treatment; microbial load.

\section{Introduction}

Beef may be the vehicle of foodborne diseases as a result of deficient sanitary conditions during animal slaughter (HERNÁNDEZ et al., 2007; LORETZ; STEPHAN; ZWEIFEL, 2011). The possibilities of eliminating pathogenic microorganisms from meat have received considerable attention in the last decades (SOFOS et al., 1999). Intervention strategies and their effects on microorganism levels have had an impact on industry economics and also on public health matters (BOLDER, 1997).

Bovine carcasses can be contaminated during the slaughter process through the contact with the animal's skin and hair, limbs, blood, stomach, gut contents, bile and other excretions, facilities, equipment, and hands and worker's clothes (RAHKIO; KORKEALA, 1997; SAMMARCO et al., 1997; SIRAGUSA et al., 1998; SMULDERS; GREER, 1998; DELAZARI et al., 1998; STOPFORTH et al., 2007; SOFOS, 2008). Carcass washing, chilling, storage (ESCUTIA, 1996, SIRAGUSA et al., 1998; McEVOY et al., 2004), and processing (BAIRD et al., 2006; KOOHMARAIE et al., 2007) can also contribute to the reduction of the final microbial load on beef.

Only a small fraction of the microbial flora is eliminated by the carcass washing procedure commonly practiced at slaughterhouses (BOUTTIER et al., 1996; BOLTON; DOHERTY; SHERIDAN, 2001), thus the preservation of meat must be guaranteed by other methods to maintain its intrinsic quality and safety (FERNANDES et al., 1998).
Many chemical compounds have been shown to reduce bacteria populations. Ransom et al. (2003) reported that chemical compounds are able to reduce the incidence of pathogens and other bacteria counts upon beef carcasses or their cuts by 1 to 3 logs (TINNEY et al., 1997; RANSOM et al., 2003). Organic acids such as acetic, citric, and lactic acid are widely used in the U.S. and Canada for carcass decontamination and are included among the different strategies for carcass (GORMAN et al., 1995; TINNEY et al., 1997; CASTILLO et al., 1998; BACON et al., 2000; LORETZ; STEPHAN; ZWEIFEL, 2011) and meat decontamination under controlled conditions at the laboratory (DORSA; CUTTER; SIRAGUSA, 1998). It is known that acetic acid inhibits mainly yeasts and bacteria as Bacillus spp., Clostridium spp., Pseudomonas spp., Campylobacter jejuni, Escherichia coli, Listeria monocytogenes, Salmonella sp. and Staphylococcus aureus (DAVIDSON; TAYLOR, 2007); it also inhibits mesophilic enteric bacteria, which are more sensitive to organic acids than the pathogenic bacteria species (SOFOS et al., 1999). However, only little data on the effect of acid solutions in microbial reduction of carcasses at slaughter plants under commercial conditions is available (ALGINO; INGHAM; ZHU, 2007; LORETZ; STEPHAN; ZWEIFEL, 2011). Therefore, the aim of this study was to evaluate the reduction in bacterial counts on beef carcass surfaces using $2 \%$ acetic acid solution at different spraying pressure and time as a carcass decontamination strategy in a commercial slaughterhouse in Mexico.

\footnotetext{
Received 14/11/2012

Accepted 31/5/2013 (005944)

1 Laboratorio de Ciencia de la Carne, Facultad de Medicina Veterinaria y Zootecnia, Universidad Nacional Autonoma de Mexico - UNAM, Circuito Exterior,

Ciudad Universitaria, CP 04510, Apartado Postal 70-483 y 70-486, Delegación Coyoacán, DF, México, e-mail: msalud@unam.mx

2 Facultad de Química, Departamento de Alimentos y Biotecnología, Universidad Nacional Autónoma de México - UNAM, Ciudad de México, DF, México

3 Departamento de Medicina Preventiva y Salud Pública, Facultad de Medicina Veterinaria y Zootecnia, Universidad Nacional Autónoma de México - UNAM,

Ciudad de México, DF, México

${ }^{4}$ School of Agricultural Sciences and Veterinary Medicine, Pontifícia Universidade Católica do Paraná - PUCPR, Curitiba, PR, Brasil

${ }^{*}$ Corresponding author
} 


\section{Materials and methods}

\subsection{Experimental design}

Carcasses were randomly selected during the bovine slaughter process at a commercial type slaughterhouse in the State of Mexico, Mexico, and gathered into five groups for treatment application as described below. The samples were collected during a period of four different working days at the slaughterhouse, hence the number of carcasses in treatments varied according to the company's slaughter schedule on each day of sample collection. However, all the treatments were performed on the sampling days.

- Non-treated group: this group was composed of 28 carcasses that were sampled to establish the initial bacteria load. Carcasses were sampled immediately after the evisceration step;

- Treatment 1: this group was composed of 45 carcasses washed twice with water from the network system at 2,100 psi for 120-180 s. The samples were taken after the washing step commonly performed during the bovine slaughter process;

- Treatment 2: composed of 18 carcasses sprayed with a $2 \%$ acetic acid solution at 10-30 psi for $60 \mathrm{~s}$, applied immediately after the evisceration step;

- Treatment 3: composed of 34 carcasses washed with water from the network system at 2,100 psi for 120-180 s and immediately sprayed with a $2 \%$ acetic acid solution at low pressure of 10-30 psi for $60 \mathrm{~s}$;

- Treatment 4: composed of 25 carcasses washed with water from the network system at 2,100 psi for 120-180 s and immediately sprayed with a $2 \%$ acetic acid solution at high pressure of 1,700 psi for $15 \mathrm{~s}$.

Each carcass in Treatments 2, 3, and 4 was sprayed with $1,000 \mathrm{~mL}$ of $2 \%$ acetic acid solution prepared from $99 \%$ glacial acetic acid (Sigma-Aldrich, MO, USA) at $22 \pm 3{ }^{\circ} \mathrm{C}$.

\subsection{Sampling protocol}

The sampling method was applied according to the European Union recommendations for bovine carcass sampling for microbiological analysis (EUROPEAN..., 2001). An area of $100 \mathrm{~cm}^{2}$ of each half-carcass was sampled by thoroughly rubbing the surface of the brisket and flank zones with sterile swabs. When different strategies were applied, the sampling was performed five to eight minutes after each treatment.

Immediately after sample collection, the swabs from the same carcass were pooled together in plastic bags containing $100 \mathrm{~mL}$ of $1 \%$ sterile peptone water at $2-4{ }^{\circ} \mathrm{C}$ and transported to the laboratory for the microbiological analysis within three hours after sampling (EUROPEAN..., 2005).

\subsection{Microbiological methods}

Counts of aerobic mesophilic (TPC), total coliform (TC), and fecal coliform (FC) were performed in the samples according to the NOM-092 and NOM-113/ SSA1-1994 of the Mexican Official Standards for total plate count and coliform count in food (MÉXICO, 1995a, b). The results were expressed as logarithmic colony forming units (log CFU) per $\mathrm{cm}^{2}$.

\subsection{Statistical analysis}

Data were analyzed by comparison of means by analysis of variance through ANOVA using SPSS 10.0 software program for windows. When significant differences were found among the treatment means $(\mathrm{P}<0.05)$, the Tukey's test was used to compare means.

\section{Results and discussion}

As shown in Table 1, non-treated carcasses showed contamination of aerobic mesophilic, total coliform, and fecal coliform at levels of $3.28 \log \mathrm{CFU} / \mathrm{cm}^{2}, 1.93 \mathrm{log} \mathrm{CFU} / \mathrm{cm}^{2}$ and $1.80 \log \mathrm{CFU} / \mathrm{cm}^{2}$, respectively. All intervention treatments, Treatments 1 to 4 , were effective to reduce total and fecal coliform counts on bovine carcasses in comparison to nontreated carcasses $(\mathrm{P}<0.05)$. In fact, washing the carcasses caused a slight increase in TPC $(\mathrm{P}<0.05)$ in relation to the non-treated carcasses. Despite the fact that water washing is routinely used in meat processing and proved to be effective in removing visible contaminants, soil, hair, or other debris (LORETZ; STEPHAN; ZWEIFEL, 2011), washing carcasses with cold and warm water not only showed hardly any reduction, but it also tended to spread bacteria on the carcass surface (BELL, 1997; JERICHO; BRADLEY; KOZUB, 1995). Ariyapitipun, Azlin and Clarke (1999) compared different intervention strategies on top round beef and found that water washes did not significantly reduce mesophilic bacteria, Enterobacteriaceae, and even Pseudomonas count on the meat samples.

Table 1. Total plate count, total coliform, and fecal coliform counts on the bovine carcasses surface before and after treatments.

\begin{tabular}{|c|c|c|c|c|}
\hline Treatments & $\begin{array}{c}\text { Carcasses } \\
\text { (n) }\end{array}$ & $\begin{array}{c}\text { Total plate count } \\
\left(\log \mathrm{CFU} / \mathrm{cm}^{2}\right)\end{array}$ & $\begin{array}{l}\text { Total coliform } \\
\left(\log \mathrm{CFU} / \mathrm{cm}^{2}\right)\end{array}$ & $\begin{array}{l}\text { Fecal coliform } \\
\left(\log \mathrm{CFU} / \mathrm{cm}^{2}\right)\end{array}$ \\
\hline Non treated & 28 & $3.28^{b}$ & $1.93^{\mathrm{a}}$ & $1.80^{\mathrm{a}}$ \\
\hline Treatment 1 & 45 & $3.90^{\mathrm{a}}$ & $1.00^{\mathrm{b}}$ & $0.77^{\mathrm{c}}$ \\
\hline Treatment 2 & 18 & $3.40^{\mathrm{ab}}$ & $1.36^{\mathrm{b}}$ & $1.30^{\mathrm{b}}$ \\
\hline Treatment 3 & 34 & $2.48^{\mathrm{c}}$ & $0.39^{c}$ & $0.40^{\mathrm{d}}$ \\
\hline Treatment 4 & 25 & $3.17^{\mathrm{b}}$ & $0.63^{c}$ & $0.52^{\mathrm{cd}}$ \\
\hline
\end{tabular}

Treat. 1 = Water washing; Treat. 2 = Acetic acid, 10-30 psi/ $60 \mathrm{~s}$; Treat. 3 = Water washing + acetic acid, 10-30 psi/ 60 s; Treat. $4=$ Water washing + acetic acid, 1700 psi/ 15 s. Means with different letters in the same column are significantly different $(\mathrm{P}<0.05)$. 
The acetic acid spraying of the carcasses after evisceration and before the washing step (Treatment 2 ) showed no differences $(\mathrm{P}>0.05)$ in aerobic mesophilic and total coliform count from the simple washing treatment (Treatment 1).

On the other hand, evidence of the effectiveness of the combination of water washing plus $2 \%$ acetic acid spraying (Treatments 3 and 4 ) is shown in this study. Both treatments 3 and 4 significantly reduced $(P<0.05)$ the contamination of the carcasses by aerobic mesophilic bacteria and coliforms although T3 (lower pressure/ longer time) showed higher level of bacterial reduction than Treatment $4(\mathrm{P}<0.05)$. The logarithmic reduction in total plate count, total coliform, and fecal coliform on beef carcasses in Treatment 3 were $0.80,1.54$, and $1.40 \log \mathrm{CFU} / \mathrm{cm}^{2}$, respectively, whereas the logarithmic reduction for the same indicator bacteria in Treatment 4 were $0.11,1.30$, and $1.28 \log \mathrm{CFU} / \mathrm{cm}^{2}$, respectively.

According to Hugas and Tsigarida (2008), acetic acid washes work better when used in combination with other interventions than alone. The use of high pressure (1,700 psi) to spray acetic acid on carcass surface might have spread some bacteria on them and hence led to lower bacterial reduction. Furthermore, it suggests that although acetic acid concentration and temperature were similar, the exposure time played an important role in the final results. On the other hand, Bacon et al. (2000) found that higher levels of microorganisms on some carcasses after spraying acetic acid can be attributed to different microbial content between animals, individual effects of removing guts, carcass washing, or another source of contamination at slaughterhouses.

Microbial reductions with acetic acid interventions on beef carcasses have been reported in other studies. Gorman et al. (1995) found average reductions in aerobic bacteria and E. coli of $2.0 \log \mathrm{CFU} / \mathrm{cm}^{2}$ and $1.9 \log \mathrm{CFU} / \mathrm{cm}^{2}$, respectively, on beef carcasses treated twice with acetic acid plus water washing at two different temperatures, first washing at $14{ }^{\circ} \mathrm{C}$ and second washing at $35^{\circ} \mathrm{C}$. Bacon et al. (2000) found a total plate count reduction of $5.5 \log \mathrm{CFU} / \mathrm{cm}^{2}$ on samples obtained after the steaming of pre-eviscerated carcasses and subsequently washing plus spraying $1.5 \%$ acetic acid at $20{ }^{\circ} \mathrm{C}$. Delazari et al. (1998) found logarithmic reduction lower than $0.3 \log \mathrm{UFC} / \mathrm{cm}^{2}$ in the number of E. coli O157:H7 after 1.5\% acetic acid spraying at $20{ }^{\circ} \mathrm{C}$ on previously contaminated beef carcasses. Tinney et al. (1997) reported total plate count bacteria reduction of $0.20 \log \mathrm{CFU} / \mathrm{cm}^{2}$ and coliforms reduction of $0.41 \log \mathrm{CFU} / \mathrm{cm}^{2}$ after spraying $2 \%$ acetic acid solution on beef carcasses.

Despite these previous reports, the consensus findings on acid interventions are that topical application of 1 to $3 \%$ organic acids to meat surfaces produces less than 2 log reduction in pathogen numbers (CARPENTER; SMITH; BROADBENT, 2011). Besides, most of the studies cited were conducted under controlled conditions and were not conducted in commercial facilities. The use of interventions at slaughter plants reduced the bacterial loads on carcasses to some extent, but the reductions were clearly lower than those obtained under laboratory conditions. Acetic acid or lactic acid treatment mainly yielded bacterial reductions below two orders of magnitude on carcasses (LORETZ; STEPHAN; ZWEIFEL, 2011).

Algino, Ingham and Zhu (2007) reported that under commercial conditions, $2.5 \%$ acetic acid solution spraying at the end of slaughter reduced naturally occurring E. coli and total coliform on carcasses by $0.71 \log \mathrm{CFU} / \mathrm{cm}^{2}$ and $0.81 \mathrm{CFU} / \mathrm{cm}^{2}$, respectively. The same authors also reported aerobic bacteria reduction higher than $0.5 \log \mathrm{CFU} / \mathrm{cm}^{2}$ in $50.81 \%$ of the carcasses. In the present study, fecal coliform reduction on carcasses treated with $2 \%$ acetic acid and water washing (T3 and T4) ranged from 1.28 to $1.40 \log \mathrm{CFU} / \mathrm{cm}^{2}$, total coliform ranged from 1.30 to 1.50 , and aerobic bacteria from 0.11 to $0.80 \log \mathrm{CFU} / \mathrm{cm}^{2}$.

A positive point of organic acid decontaminate interventions is that the antimicrobial action of acids goes beyond their spraying on carcasses. Their action after spraying may be of particular importance for the control of pathogens because rapid proliferation of pathogens can take place in decontaminated carcasses. Acid washing with acetic acid imparts residual inhibition of pathogens from a short-term bactericidal effect for about 2 days after washing. (CARPENTER; SMITH; BROADBENT, 2011).

According to the European criteria for beef carcass contamination (EUROPEAN..., 2005), Enterobacteriaceae count lower than $1.5 \log \mathrm{CFU} / \mathrm{cm}^{2}$ and aerobic bacteria count lower than $3.5 \log \mathrm{CFU} / \mathrm{cm}^{2}$ are considered satisfactory. All samples (100\%) in the treatment interventions (T1, T2, T3 and T4) showed average coliform count (TC and FC) lower than that of the standard (Table 1). Regarding the count of aerobic bacteria, only the samples in the water washing treatment (T1) had higher average count than that of the microbiological standard.

Concerning the ranges of microbiological counts on beef carcasses treated with acetic acid plus water washing, 100\% of sample in Treatment 3 and $92 \%$ of samples in Treatment 4 presented total coliform count lower than $2.0 \log \mathrm{CFU} / \mathrm{cm}^{2}$ (Table 2). For fecal coliform, $100 \%$ of samples in Treatment 3 and $96 \%$ in Treatment 4 showed counts lower than $2.0 \log \mathrm{CFU} / \mathrm{cm}^{2}$ (Table 3). For aerobic bacteria, $100 \%$ of samples in Treatment 3 and $72 \%$ in Treatment 4 presented total plate count lower than

Table 2. Frequency distribution for total coliform levels on beef carcasses before and after intervention treatments.

\begin{tabular}{|c|c|c|c|c|c|c|}
\hline \multirow{2}{*}{$\begin{array}{c}\text { Intervention } \\
\text { treatments }\end{array}$} & \multirow{2}{*}{$\begin{array}{l}\text { Carcasses } \\
\text { (n) }\end{array}$} & \multicolumn{5}{|c|}{ Carcasses (\%) with total coliform levels at indicated $\log \mathrm{CFU} / \mathrm{cm}^{2}$} \\
\hline & & Non detected & $0.1-1.0$ & $1.1-2.0$ & $2.1-3.0$ & $>3.0$ \\
\hline Non treated & 28 & 0.00 & 21.42 & 32.14 & 25.00 & 21.42 \\
\hline Treatment 1 & 45 & 0.00 & 68.88 & 20.00 & 8.88 & 2.22 \\
\hline Treatment 2 & 18 & 0.00 & 50.00 & 38.88 & 0.00 & 11.11 \\
\hline Treatment 3 & 34 & 29.41 & 64.70 & 5.88 & 0.00 & 0.00 \\
\hline Treatment 4 & 25 & 56.00 & 12.00 & 24.00 & 8.00 & 0.00 \\
\hline
\end{tabular}

Treat. 1 = Water washing; Treat. 2 = Acetic acid, $10-30$ psi $/ 60 \mathrm{~s}$; Treat. $3=$ Water washing + acetic acid, $10-30$ psi/ $60 \mathrm{~s}$; Treat. $4=$ Water washing + acetic acid, 1700 psi $/ 15 \mathrm{~s}$. 
Table 3. Frequency distribution for fecal coliform levels on beef carcasses before and after intervention treatments.

\begin{tabular}{|c|c|c|c|c|c|c|}
\hline \multirow{2}{*}{$\begin{array}{c}\text { Intervention } \\
\text { treatments }\end{array}$} & \multirow{2}{*}{$\begin{array}{c}\text { Carcasses } \\
\text { (n) }\end{array}$} & \multicolumn{5}{|c|}{ Carcasses (\%) with fecal coliform levels at indicated log CFU/ $\mathrm{cm}^{2}$} \\
\hline & & Non detected & $0.1-1.0$ & $1.1-2.0$ & $2.1-3.0$ & $>3.0$ \\
\hline Non treated & 28 & 0.00 & 21.42 & 42.85 & 25.00 & 16.66 \\
\hline Treatment 1 & 45 & 31.11 & 46.66 & 15.55 & 6.66 & 0.00 \\
\hline Treatment 2 & 18 & 0.00 & 50.00 & 33.33 & 11.11 & 5.55 \\
\hline Treatment 3 & 34 & 29.41 & 64.70 & 5.88 & 0.00 & 0.00 \\
\hline Treatment 4 & 25 & 52.00 & 20.00 & 24.00 & 4.00 & 0.00 \\
\hline
\end{tabular}

Treat. 1 = Water washing; Treat. 2 = Acetic acid, 10-30 psi $60 \mathrm{~s}$; Treat. 3 = Water washing + acetic acid, 10-30 psi/ $60 \mathrm{~s}$; Treat. $4=$ Water washing + acetic acid, 1700 psi/ $15 \mathrm{~s}$.

Table 4. Frequency distribution for aerobic plate count levels on beef carcasses before and after intervention treatments.

\begin{tabular}{cccccc}
\hline Intervention & Carcasses & \multicolumn{3}{c}{ Carcasses (\%) with aerobic bacteria levels at indicated log CFU/ $\mathrm{cm}^{2}$} \\
\cline { 3 - 6 } treatments & $(\mathrm{n})$ & Non detected & $0.1-2.0$ & $2.1-3.0$ & $3.1-4.0$ \\
\hline Non treated & 28 & 21.42 & 0.00 & 0.00 & 42.85 \\
Treatment 1 & 45 & 0.00 & 0.00 & 0.00 & 86.66 \\
Treatment 2 & 18 & 0.00 & 0.00 & 0.00 & 100.00 \\
Treatment 3 & 34 & 0.00 & 20.58 & 64.70 & 14.70 \\
Treatment 4 & 25 & 0.00 & 24.00 & 24.00 & 0.00 \\
\hline
\end{tabular}

Treat. 1 = Water washing; Treat. $2=$ Acetic acid, $10-30 \mathrm{psi} / 60 \mathrm{~s}$; Treat. $3=$ Water washing + acetic acid, $10-30$ psi $60 \mathrm{~s}$; Treat. $4=$ Water washing + acetic acid, 1700 psi $/ 15 \mathrm{~s}$.

$4.0 \log \mathrm{CFU} / \mathrm{cm}^{2}$ (Table 4). However, none of the samples of both treatments showed aerobic count higher than $5.0 \log \mathrm{CFU} / \mathrm{cm}^{2}$.

Enterobacteriaceae count ranging from 1.5 to $2.5 \log \mathrm{CFU} / \mathrm{cm}^{2}$ and aerobic bacteria count ranging from 3.5 to $5.0 \log \mathrm{CFU} / \mathrm{cm}^{2}$ are considered acceptable by the European microbiological criteria (EUROPEAN..., 2005).

\section{Conclusions}

The large bacterial reductions observed in the present study indicate that spraying a $2 \%$ acetic acid solution after carcass washing can be used successfully to reduce populations of indicator microorganisms and thus control a major source of pathogenic bacteria on beef carcasses under commercial conditions. Additionally, it is a cheap strategy, and it does not imply that the facility should be renovated.

It is important to mention that Good Manufacturing Practices at slaughterhouses must be followed and decontamination treatments always must be considered part of an integral food safety system (LORETZ; STEPHAN; ZWEIFEL, 2011), and they should not be used to hide possible malpractice.

\section{Acknowledgements}

The authors acknowledge the financial support of UNAM trough project PAPIIT IN, number 222606-2.

\section{References}

ALGINO, R. J.; INGHAM, S. C.; ZHU, J. Survey of antimicrobial effects of beef carcass intervention treatments in very small state-inspected slaughter plants. Journal of Food Science, v. 72, p. 173-179, 2007. PMid:17995740. http://dx.doi.org/10.1111/j.17503841.2007.00386.x
ARIYAPITIPUN, T.; AZLIN, M.; CLARKE, A. D. Microbial shelf life determination of vacuum-packaged fresh beef treated with polilactic acid, lactic acid and nisin solutions. Journal of Food Protection, v. 62, p. 913-920, 1999. PMid:10456746.

BACON, R. T. et al. Comparison of three commercial beef carcass decontamination systems. The Department of Animal Sciences Colorado State University, 2000. Research Report.

BAIRD, B. E. et al. Beef hide antimicrobial interventions as a means of reducing bacterial contamination. Department of Animal Science, Texas Agricultural Experiment Station, Texas A\&M University, Meat Science Section, 2471 MTAMU, College Station, TX 778432471, USA, 2006.

BELL, R. G. Distribution and sources of microbial contamination on beef carcasses. Journal of Applied Microbiology, v. 82, p. 292-300, 1997. PMid:12455892. http://dx.doi.org/10.1046/j.13652672.1997.00356.x

BOLDER, N. M. Decontamination of meat and poultry carcasses. Review. Trends in Food Science \& Technology, v. 8, p. 221-227, 1997. http://dx.doi.org/10.1016/S0924-2244(97)01040-6

BOLTON, D. J.; DOHERTY, A. M.; SHERIDAN, J. J. Beef HACCP: intervention and non-intervention systems. International Journal of Food Microbiology, v. 66, p. 119-129, 2001. http://dx.doi. org/10.1016/S0168-1605(00)00528-6

BOUTTIER, S. et al. Attachment of Salmonella cholerasuis cholerasuis to beef muscle and adipose tissues. Journal of Food Protection, v. 60, p. 16-22, 1996.

CARPENTER, C. E.; SMITH, J. V.; BROADBENT, J. R. Efficacy of washing meat surfaces with $2 \%$ levulinic, acetic, or lactic acid for pathogen decontamination and residual growth inhibition. Meat Science, v. 88, p. 256-260, 2011. PMid:21251765. http://dx.doi. org/10.1016/j.meatsci.2010.12.032

CASTILLO, A. et al. Decontamination of beef carcass surface tissue by steam vacuuming alone and combined with hot water and lactic acid sprays. Journal of Food Protection, v. 61, p. 823-828, 1998. PMid:9678163. 
DAVIDSON, M. P.; TAYLOR, T. M. Chemical preservatives and natural compounds. In: DOYLE, M. P.; BEUCHAT, L. R.; MONTVILLE, T. J. (Ed.). Food Microbiology Fundamentals and Frontiers. 3. ed. Washington: ASM Press, 2007. p. 713-735.

DELAZARI, I. et al. Decontaminating beef for Escherichia coli O157:H7. Journal of Food Protection, v. 61, p. 547-550, 1998. PMid:9709225.

DORSA, W. J.; CUTTER, C. N.; SIRAGUSA, G. R. Long-term effect of alkaline, organic acid or hot water washes on the microbial profile of refrigerated beef contaminated with bacterial pathogens after washing. Journal of Food Protection, v. 61, p. 300-306, 1998. PMid:9708300.

ESCUTIA, I. S. Análisis de Riesgos e Identificación de Puntos Críticos de Control en el Procesamiento de Canales de Bovino para el Abasto en un Rastro Municipal Tipo del Estado de México. D.F. 1996. 100 f. Dissertation (M.Sc. in Animal Production)Facultad de Medicina Veterinaria y Zootecnia, 1996.

EUROPEAN UNION. L 165/48. European Directive 2001/471/EC laying down rules for the regular checks on the general hygiene carried out by the operators in establishments. The Official Journal of the European Communities, 8 June 2001.

EUROPEAN UNION. L 338/1 22.12.2005. Regulation (CE) $n^{\circ} 2073 / 2005$ of the Commission of European Communities for the microbiological criteria applicable to food products. European Union Official Diary, 15 Nov 2005.

FERNANDES, C. F. et al. Role of organic acids during processing to improve quality of channel catfish fillets. Journal of Food Protection, v. 61, p. 495-498, 1998. PMid:9709217.

GORMAN, B. M. et al. Evaluation of hand-trimming, various sanitizing agents, and hot water spray washing as decontamination interventions for beef brisket adipose tissue. Journal of Food Protection, v. 58, p. 899-907, 1995.

HERNÁNDEZ, S. S. J. et al. Microbiological conditions during the slaughter process at a municipal slaughterhouse in Hidalgo, México. Veterinaria Mexico, v. 38, p. 187-195, 2007.

HUGAS, M.; TSIGARIDA, E. Pros and cons of carcass decontamination: The role of the European Food Safety Authority. Meat Science, v. 78, p. 43-52, 2008. PMid:22062094. http://dx.doi.org/10.1016/j. meatsci.2007.09.001

JERICHO, K. W.; BRADLEY, J. A.; KOZUB, G. C. Microbiologic evaluation of carcasses before and after washing in a beef slaughter plant. Journal of American Veterinary Medicine Association, v. 206, p. 452-455, 1995. PMid:7632246.

KOOHMARAIE, M. et al. Interventions to reduce/eliminate Escherichia coli O157:H7 in ground beef. Meat Science, v. 77, p. 90-96, 2007. PMid:22061399. http://dx.doi.org/10.1016/j.meatsci.2007.04.004

LORETZ, M.; STEPHAN, R.; ZWEIFEL, C. Antibacterial activity of decontamination treatments for cattle hides and beef carcasses. Meat Science, v. 88, p. 256-260, 2011.
McEVOY, J. M. et al. Microbial contamination on beef in relation to hygiene assessment based on criteria used in EU Decision 2001/471/ EC. International Journal of Food Microbiology, v. 92, p. 217-225, 2004. PMid:15109799. http://dx.doi.org/10.1016/j. ijfoodmicro.2003.09.010

MÉXICO. Secretaría de Salud. Norma Oficial Mexicana. NOM-092SSA1-1994, Bienes y Servicios. Método para la cuenta de bacterias aerobias en placa. Diario Oficial, México, 10 Nov 1995a. Disponível em: http://www.salud.gob.mx/unidades/cdi/nom/092ssa14.html>.

MÉXICO. Secretaría de Salud. Norma Oficial Mexicana. NOM113-SSA1-1994, Bienes y Servicios. Método para la cuenta de microorganismos coliformes en placa. Diario Oficial, México, 10 May 1995b. Disponível em: <http://www.salud.gob.mx/unidades/ cdi/nom/113ssa14.html>.

RAHKIO, T. M.; KORKEALA, H. J. Airborne bacteria and carcass contamination in slaughterhouses. Journal of Food Protection, v. 60, p. 38-42, 1997. PMid:10465038.

RANSOM, J. R. et al. Comparison of intervention technologies for reducing Escherichia coli O157:H7 on beef cuts and trimmings. Food Protection Trends, v. 23, p. 24-34, 2003.

SAMMARCO, L. M. et al. Prevalence of Salmonellae, Listeriae and Yersiniae in the slaughterhouse environment and on work surfaces, equipment and workers. Journal of Food Protection, v. 60, p. 367371, 1997.

SIRAGUSA, G. R. et al. The incidence of Escherichia coli on beef carcasses and its association with aerobic mesophilic plate count categories during the slaughter process. Journal of Food Protection, v. 61, p. 1269-1274, 1998. PMid:9798140.

SMULDERS, F. J. M.; GREER, G. C. Integrating microbial decontamination with organic acids in HACCP programs for muscle foods: prospects and controversies. International Journal of Food Microbiology, v. 44, p. 149-169, 1998. http://dx.doi.org/10.1016/ S0168-1605(98)00123-8

SOFOS, J. N. et al. Incidence of Salmonella on beef carcasses relating to the U.S. meat and poultry inspections regulations. Journal of Food Protection, v. 62, p. 467-473, 1999. PMid:10340666.

SOFOS, J. N. Challenges to meat safety in the 21 st century. Meat Science, v. 78, p. 3-13, 2008. PMid:22062090. http://dx.doi. org/10.1016/j.meatsci.2007.07.027

STOPFORTH, J. D. et al. Acid tolerance of acid-adapted and nonacidadapted Escherichia coli O157:H7 strains in beef decontamination runoff fluids or on beef tissue. Food Microbiology, v. 24, p. 530-538, 2007. PMid:17367686. http://dx.doi.org/10.1016/j. fm.2006.05.007

TINNEY, K. S. et al. Reduction of microorganisms on beef surfaces with electricity and acetic acid. Journal of Food Protection, v. 60, p. 625-628, 1997. 